\title{
Implementation of STEM Learning Method to Develop Children's Critical Thinking and Problem Solving Skills
}

\author{
Ruth Debora ${ }^{\otimes}$, Rudy Pramono ${ }^{1}$ \\ Teknologi Pendidikan, Universitas Pelita Harapan, Indonesia(1) \\ DOI: $10.31004 /$ obsesi.v6i3.1722
}

\begin{abstract}
Abstrak
Adanya perubahan dari pembelajaran tatap muka menjadi pembelajaran virtual pada jenjang Pendidikan Anak Usia Dini selama pandemi COVID-19 menjadi tantangan bagi tenaga pengajar. Penggunaan metode pembelajaran yang tepat dibutuhkan untuk mendukung pertumbuhan dan perkembangan anak selama pembelajaran virtual dilakukan. Penelitian ini bertujuan untuk mengetahui dampak dari penggunaan metode pembelajaran STEM dalam upaya meningkatkan kemampuan berpikir kritis dan pemecahan masalah dalam pembelajaran virtual. Metode penelitian yang digunakan adalah Penelitian Tindakan Kelas dengan menggunakan Model Kemmis dan McTaggart dalam 3 siklus dengan teknik pengumpulan data observasi dan dokumentasi. Subyek dari penelitian ini adalah 10 anak berusia 3 hingga 4 tahun yang mengikuti kegiatan pembelajaran virtual. Hasil penelitian menunjukkan bahwa dengan adanya tindakan perbaikan yang dilakukan dalam kegiatan pembelajaran, terjadi peningkatan kemampuan berpikir kritis dan pemecahan masalah anak yang terlihat dari peningkatan tingkat klasifikasi perkembangan partisipan pembelajaran dari Siklus 1 hingga Siklus 3.
\end{abstract}

Kata Kunci: penelitian tindakan kelas; pembelajaran stem; kemampuan berpikir kritis; kemampuan pemecahan masalah; keterlibatan partisipan dalam pembelajaran.

\begin{abstract}
The change from face-to-face learning to virtual learning at the Early Childhood Education level during the COVID-19 pandemic is a challenge for teaching staff. The use of appropriate learning methods is needed to support the growth and development of children during virtual learning. This study aims to determine the impact of using STEM learning method to improve children's critical thinking and problem solving skills. The research method used is Classroom Action Research using Kemmis and McTaggart Models in 3 cycles with observation and documentation data collection techniques. The subjects of this study were 10 children aged 3 to 4 years who took part in virtual learning activities. The results showed that with corrective actions taken in learning activities, there was an increase in children's critical thinking and problem solving skills as seen from the increase in the level of criteria of the development of learning participants from First to Third Cycle.
\end{abstract}

Keywords: classroom action research, stem learning, critical thinking skills, problem solving skills, children's engagement in learning.

Copyright (c) 2021 Ruth Debora, Rudy Pramono.

$\square$ Corresponding author:

Email Address : the.ruthdebora@gmail.com (Tanggerang, Banten, Indonesia)

Received 5 May 2021, Accepted 25 August 2021, Published 28 August 2021 


\section{INTRODUCTION}

Any form of effort to prepare children 0 to 6 years for the next level of education through conscious and planned learning is the definition of Early Childhood Education or ECE. The main principle of the ECE learning program is to support the optimal development of students, both physically and spiritually. The learning programs developed are childoriented and adapted to the needs and uniqueness of each child. Children are encouraged to be actively involved in the learning process carried out through various games (Wiyani, 2016). (Gogoi, 2015) added that learning with the hands-on method for early childhood provides space for children to be directly involved interactively with the learning process using their five senses. To support the early childhood learning process well, the learning environment and learning materials need to be well prepared, so that each party involved in PAUD not only supports and develops children's potential from various aspects of development, but can also stimulate children's creativity (Wiyani, 2016)

In Indonesian Curriculum for Early Childhood Education, the Developmental Achievement Level Standard is listed as a qualification for child development, and one of the aspects of child development listed in it is the cognitive aspect. There are three important aspects that need to be considered related to the cognitive development of children. The first aspect is the child's ability to solve simple problems in everyday life. The way children apply their knowledge or experience to create a new concept becomes observable. The second aspect is the ability of children to think logically, which includes the ability to distinguish, classify, and recognize the concept of cause and effect. Children's ability to think symbolically, namely the ability to recognize numbers, letters, and objects around them, is the last aspect to be observed. These three aspects are then further elaborated in the basic competencies used by educators to observe children (Ulfah \& Junaedah, 2018). Children's cognitive development is closely related to a child's thinking ability. When children's cognitive aspects develop optimally, then they have built a foundation of basic thinking framework to solve various problems, as well as develop their ability to think creatively and critically (Suryana, 2016). León $(2015,115)$ adds that in the early childhood group, one of the cognitive developments that needs to be considered is the ability of children's thought processes to help children process the information they receive.

Critical thinking skills is a person's ability to process and analyze the information received to make conclusions about the assessment of the information. In Early Childhood this ability is marked by the child's ability to ask questions and find out about information, form their own opinions, have a rational attitude by recognizing real and logical evidence, as well as comparing and categorizing the information obtained as a form of analysis (Natalina M., 2018). Children who have good critical thinking skills can provide appropriate responses and are able to apply the results of the analysis of the information obtained in various situations (Stella, 2017). The implementation of learning in schools, including the learning methods and facilities used, has an influence on the development of children's critical thinking skills (Melo León, 2015). (Kamarulzaman, 2015) stated that learning while playing is one of the appropriate learning strategies for early childhood. When children play, they can explore freely and be directly involved in learning. Learning that provides space for children to be able to solve problems and make decisions independently and creatively is also one of the learning strategies that can be used to improve children's critical thinking skills (Risnanosanti et al., 2019).

In addition to critical thinking skills, children's ability to solve problems also has a close relationship in children's cognitive development. Problems are something that every individual encounter in daily life. The existence of a gap between the expected conditions and the conditions that occur creates a need in an individual to solve existing problems. In Early Childhood, problem solving ability is a child's ability to solve problems in various ways as indicated by the child's ability to understand problems, make designs to solve problems, and apply and evaluate the results of problem-solving designs. Problem solving skills in children 
can affect children's skills to adapt to solve problems, have the ability to think systematically, critically, and logically, as well as train children to take positive actions and help children in dealing with conflicts in everyday life (Dyah \& Setiawati, 2019). In improving problem solving skills in children, appropriate learning strategies are needed. (Fettig et al., 2016) stated that in the Early Childhood learning environment, it is necessary to apply four problem-solving steps, namely identifying existing problems, thinking about appropriate solutions, thinking about what happens when the solutions are implemented, and trying solutions that have been designed. These four steps can be integrated in various learning activities. Educators need to encourage children to observe and be directly involved in solving existing problems. Active learning that can be child-centered is considered to be able to improve children's problem solving abilities (Tientongdee, 2018).

COVID-19 pandemic has caused changes in the world of education at various levels, including Early Childhood Education. Various learning institutions, formal and non-formal, offer virtual learning as an alternative so that the learning process can be continued. Virtual learning is a learning process using electronic media and other technological means to achieve learning objectives. Virtual learning can be done in two ways, namely synchronous and asynchronous. Synchronous virtual learning is carried out at the same time and there is direct interaction between teachers and students using video conferencing and live chat features. In asynchronous virtual learning, students can learn independently, at a time determined by the students by using forum, web logs, and e-mail (Lim, 2017).

Although this virtual learning can be an alternative that can be done during this pandemic, there are still many pros and cons that occur. The consideration of parents regarding restrictions on the use of electronic media for Early Childhood is one of the obstacles to the virtual learning process. The use of technological devices is considered to be able to develop children's linguistic and psychomotor skills (George S. Morrison, 2014), as well as increase learning motivation which has an impact on their socio-emotional development (Kingsley S. \& Ismail Z, 2015). On the other hand, virtual learning is considered to be able to cause cognitive overload in children with complex stimulation. This condition can reduce a child's ability to process and understand information, as well as the ability to empathize, cooperate, and make friends with classmates (Jha \& Arora, 2020). Prolonged use of electronic devices can also cause negative habits in children and hinder child development. (Joseph et al., 2019) added that the use of technology needs to be limited to a maximum of 1 hour per day because it is considered to be able to inhibit children's social growth and keep children away from physical activities that are beneficial for their motor development. In addition, teaching staffs also experience obstacles in finding appropriate learning methods and media, so that the learning process and children's exploration are hampered (Agustin et al., 2020).

Wulandari \& Purwanta (2020) stated that from research conducted on the achievement of Early Childhood development during virtual learning, there was a decline in various aspects of development. The results of this study are reinforced by the problems found by researchers in a virtual class for children aged 3-4 years. Overall, the results of the observations made by researcher showed that the level of critical thinking skills and problem solving abilities of learning participants was still not good, because $70 \%$ of the participants were still in the "Undeveloped" and "Started to Develop" classifications. In the aspect of critical thinking skills, 4 participants were in the "Undeveloped" classification, 3 participants were in the "Started to Develop" classification, 1 participant was in the "Developed As Expected" classification, and only 2 participants were already in the "Extremely Well Developed" classification. Judging from the aspect of problem solving skills, 4 participants were in the "Undeveloped" classification, 3 participants were in the "Started to Develop" classification, and 3 participants were in the "Developed as Expected" classification. Most of the participants tend to be passive and quiet during learning activities and have difficulty to focus. These findings indicate that action is needed to be able to increase the level of achievement of participant development, especially in the aspects of critical thinking and problem solving skills. 
With the problems occurs, teachers need to create learning activities that can support children's development while minimizing the negative effects of virtual learning, and STEM learning method can be one of the solutions. STEM learning method is one of the learning methods developed in Indonesia. STEM itself is an acronym for Science, Technology, Engineering, and Mathematics, where learning can be integrated in four fields, namely science, technology, engineering, and mathematics. Science can be defined as knowledge about the natural surroundings obtained from facts that have been previously researched through experiments and observations. Technology itself can be interpreted as anything that can be used to solve existing problems. Engineering is the use of scientific methods to do business in designing or creating a new system or product. Mathematics is a science that is closely related to numbers, number operations, relationships, combinations, generalizations and their structures, measurements, and transformations (Siantajani, 2020).

STEM learning method provides direct experience and involves children directly to solve concrete problems that occur. Learning with the STEM method can train children's thinking, stimulate children's curiosity, and allow children to explore to find solutions to existing problems (Siantajani, 2020). Scientific skills, including the ability to reason and think critically, as well as children's problem solving can be improved through the application of STEM learning method. This child-centered learning method also increases the engagement and active role of children in learning (Struyf et al., 2019). (Peterson et al., 2016) stated that the purpose of STEM learning method is to encourage children to collaborate, think critically, and be creative, as well as to increase the level of children's success in learning. STEM learning method can be one of the learning methods that can bring positive impact on children's critical thinking skills, because children are directly involved in learning to encourage children using a scientific approach in investigating existing information (Ardianti et al., 2020). (Purwaningsih et al., 2020) added that STEM learning method encourages children to find solutions to a problem by using a variety of different perspectives, so that it becomes one of the learning methods that has the potential to improve children's problem solving abilities.'

This study was conducted to see the implementation STEM learning method on virtual learning for 3-4 year old children to improve critical thinking and problem solving skills. The results of this study are expected to assist educator in improving the quality of virtual learning for Early Childhood and increase children.

\section{METHODOLOGY}

This study was conducted using the Classroom Action Research (CAR) method. with the Kemmis and McTaggart model which was carried out in three cycles. Each cycle was carried out in 3 meetings, with a total of 9 meetings. Corrective actions are carried out in several cycles or periods until the research objectives are achieved. According to (Widayati, 2014), in CAR there are four important stages that are carried out by researchers repeatedly, namely planning, action, observation, and reflection. The design of STEM learning method implementation in a virtual class for 3-4 years age group to learn about weathers can be seen in Table 1.

The subject of this study was ten children in 3-4 years age group, who took part in a virtual learning program. The virtual learning carried out is non-formal learning with the assistance of parents or caregivers, using the Zoom Meetings application. The study was conducted for nine meeting sessions from February to March 2021 to see the impact of applying the STEM learning method in an effort to improve critical thinking skills, problem solving skills, and children's engagement in learning. The researcher acted as a classroom teacher and worked with a non-formal education center in Jakarta, Indonesia to design learning activities used in the research. Data collection technique that was being used in this study are observation and documentation. 
Table 1. The design of STEM Learning Method Implementation

\begin{tabular}{|c|c|c|c|c|}
\hline Cycle & Meeting & Actions & Theme/Subtheme & Materials \\
\hline \multirow[t]{3}{*}{1} & 1 & $\begin{array}{l}\text { Students learn to } \\
\text { understand and } \\
\text { apply their }\end{array}$ & Sunny Day & $\begin{array}{l}\text { Pictures that represent sunny day, flour, } \\
\text { water, oil }\end{array}$ \\
\hline & 2 & $\begin{array}{l}\text { understanding } \\
\text { about three } \\
\text { different weathers }\end{array}$ & Windy Day & $\begin{array}{l}\text { Pictures and video that represent windy } \\
\text { day, straws in different sizes, fan, } \\
\text { different objects (tissue, paper, cup, } \\
\text { toy, cardboard) }\end{array}$ \\
\hline & 3 & $\begin{array}{l}\text { through discussion } \\
\text { and experiment } \\
\text { activities }\end{array}$ & Rainy Day & $\begin{array}{l}\text { Pictures and video that represent rainy } \\
\text { day, cup with holes, bucket or } \\
\text { container, water in a bottle or a cup. }\end{array}$ \\
\hline \multirow[t]{3}{*}{2} & 1 & $\begin{array}{l}\text { Students learn to } \\
\text { evaluate and } \\
\text { analyze the } \\
\text { characteristics of }\end{array}$ & Sunny Day & $\begin{array}{l}\text { Pictures that represent } \\
\text { characteristics of sunny day, } \\
\text { transparent jar, milk, water, cup, } \\
\text { flashlight. }\end{array}$ \\
\hline & 2 & $\begin{array}{l}\text { three different } \\
\text { weathers through } \\
\text { discussion and } \\
\text { experiment }\end{array}$ & Windy Day & $\begin{array}{l}\text { Pictures that represent } \\
\text { characteristics of windy day, } \\
\text { balloon, plastic bottle, two } \\
\text { containers, hot and cold water. }\end{array}$ \\
\hline & 3 & activities & Rainy Day & $\begin{array}{l}\text { Pictures that represent } \\
\text { characteristics of rainy day, plastic } \\
\text { jar, sponge, water, cup, sauce bottle, } \\
\text { blue food coloring. }\end{array}$ \\
\hline \multirow[t]{3}{*}{3} & 1 & $\begin{array}{l}\text { Students learn to } \\
\text { make an object to } \\
\text { represent three } \\
\text { different weathers }\end{array}$ & Sunny Day & $\begin{array}{l}\text { Pictures that represent things that } \\
\text { can be used on a sunny day, two } \\
\text { tissue rolls, tape or glue, scissors, } \\
\text { colorful plastic, ribbon, cardboard }\end{array}$ \\
\hline & 2 & $\begin{array}{l}\text { through discussion } \\
\text { and experiment } \\
\text { activities }\end{array}$ & Windy Day & $\begin{array}{l}\text { Pictures that represent things that } \\
\text { can be used on a windy day, string, } \\
\text { tissue, flannel, plastic, three bowls, } \\
\text { tape, scissors. }\end{array}$ \\
\hline & 3 & & Rainy Day & $\begin{array}{l}\text { Pictures that represent things that } \\
\text { can be used on a s day, four popsicle } \\
\text { sticks, tape or rubber, foil cup, } \\
\text { cupcake liner, plastic bowl, }\end{array}$ \\
\hline
\end{tabular}

Data analysis was carried out to see the achievement of the development of critical thinking and problem solving skills carried out in the following steps: 1) give a score for each assessment criteria that have been observed in accordance with the assessment sheet compiled based on the assessment rubric. 2) Summing the overall score of the assessment criteria with the formula:

$$
\text { Criterion Score }=\frac{\text { Total score obstained from } 3 \text { observers }}{3}
$$

3) Determine the value based on the score of each assessment indicator with the formula:

$$
\text { Score }=\frac{\text { Gain score }}{\text { Maximum score }} \times 100 \%
$$

If $80 \%$ of participants can reach the criteria of "Developed As Expected" (DE) and "Extremely Well Developed" (ED), then the corrective action is considered successful in improving the critical thinking and problem solving skills of the participants. 


\section{RESULTS AND DISCUSSIONS}

\section{First Cycle}

The planning stage of the first cycle was done as the teacher planned learning activities that related to the "Weather" theme. The activities were aimed to help research participants understand and apply participants' understanding of three types of weather, namely "Sunny Day", "Windy Day", and "Rainy Day" by using the STEM learning method which is carried out through discussion and experiment activities. The learning theme about "Weather" was chosen because it is one of the learning materials that is closely related to the participants' daily lives, so that each participant already has prior knowledge about "Weather".

The first cycle was held on 16, 18, and 23 February 2021 in three meetings, each held for 30 minutes. Learning activities are carried out from 17.00 to 17.30 WIB with assistance from parents or caregivers from each participant. In this cycle, the implementation of learning activities is carried out in three stages of activity, namely introduction, core activity, and closing. Learning activities carried out with the Zoom Meetings application were recorded by the teacher who acted as a researcher as a documentation.

During the introduction stage, teacher greeted each participant and invited each participant to sing the greeting song, explained the rules applied in learning activities, introduced the theme of the learning that will be carried out, explained the purpose of the learning activities carried out, and prepared participants for the core activities by asking each participant to point their thumbs at the screen to indicate the participants' readiness to take part in the next activity. To begin the core activity stage, the teacher did an open discussion about different weathers and encouraged participants to share their opinions. After some participants gave their responses, the teacher invited the participants to carry out the experiment activities by mentioning the tools and materials that would be used and encouraged participants to share their predictions about what would be done and the results that would be obtained. The experimental activities were carried out with assistance from parents or caregivers from participants, but participants were still encouraged to be actively involved. After all the experiment activities were done, teacher invited each participant to discuss the activities that had been carried out to make conclusions together. The teacher would gave a brief explanation about the activities, before introducing the activities that would be done on the next learning session.

Based on observations, some participants were already actively involved in learning activities in the First Cycle. There were several participants who gave responses or questions in discussion activities, and were directly involved in conducting the experiment activities carried out at each meeting session. Some participants still had difficulty in participating in all learning activities, had short attention span, felt hesitant to answer, and still very dependent on their parents or caretaker in carrying out the experiment activities. The results of the First Cycle can be seen in Table 2 and Table 3.

Table 2. Comparison Results for Critical Thinking Skills in First Cycle

\begin{tabular}{lcccc}
\hline Criteria & $\begin{array}{c}\text { Before Any Actions Taken } \\
\text { Frequency }\end{array}$ & \multicolumn{2}{c}{ First Cycle } \\
Percentage & Frequency & Percentage \\
\hline UD & 4 & $40 \%$ & 3 & $30 \%$ \\
SD & 3 & $30 \%$ & 1 & $10 \%$ \\
DE & 1 & $10 \%$ & 4 & $40 \%$ \\
ED & 2 & $20 \%$ & 2 & $20 \%$ \\
Total & 10 & 100 & 10 & 100 \\
\hline
\end{tabular}

Note : UD (Undeveloped), SD (Started to Develop), DE (Developed as Expected), ED (Extremely WellDeveloped)

Table 2 and 3 shows that after the action design was carried out, there was an increase in the level of learning achievement of participants. In the First Cycle, $60 \%$ of participants has reached the criteria of "Developed As Expected" (DE) and "Extremely Well Developed" (ED) 
for critical thinking skills aspect, and for the problem solving skills aspects, $50 \%$ of participants has reached the criteria of "Developed As Expected" (DE) and "Extremely Well Developed" (ED). The results indicate that corrective action still needed to be taken to improve children's critical thinking and problem solving skills.

Table 3. Comparison Results for Problem Solving Skills in First Cycle

\begin{tabular}{ccccc}
\hline Criteria & \multicolumn{2}{c}{ Before Any Actions Taken } & \multicolumn{2}{c}{ First Cycle } \\
& Frequency & Percentage & Frequency & Percentage \\
\hline UD & 4 & $40 \%$ & 3 & $30 \%$ \\
SD & 3 & $30 \%$ & 2 & $20 \%$ \\
DE & 3 & $30 \%$ & 3 & $30 \%$ \\
ED & 0 & $0 \%$ & 2 & $20 \%$ \\
Total & 10 & $100 \%$ & 10 & $100 \%$ \\
\hline
\end{tabular}

Note : UD (Undeveloped), SD (Started to Develop), DE (Developed as Expected), ED (Extremely WellDeveloped)

Based on the results of observations made in First Cycle, researcher took some notes that could be used as a reflection of the learning activities in the First Cycle to optimize learning activities in Second Cycle. The experiment activities carried out were quite interesting for participants to be actively involved in learning, but the exploration time and explanations were too long, so some participants tended to lose their focus in learning. Some participants tended to be quiet during discussion, so teacher needed to give more encouragement or special opportunities for some participants to answer the questions. Teacher still tended to explain existing problems, and had not involved participants in making conclusions, so that participants were not given the opportunity to identify problems and make conclusions from the learning activities carried out.

\section{Second Cycle}

The Second Cycle in this research was carried out on February 25, March 2 and 4, 2021 in three meetings, each of which was conducted for 30 minutes on Tuesday and Thursday. In this cycle, the teacher still used the same learning theme, "Weather", based on the enthusiasm and interest of the participants to learn more about the weather. In an effort to develop aspects of critical thinking and problem solving skills, the teacher designed learning activities with the aim of encouraging participants to be able to evaluate and analyze the characteristics of the three types of weather that have been studied in the previous three meetings. Several corrective actions that were being implemented as the result of reflection stage from the First Cycle, such as shortened exploration time, provided a shorter explanation of learning materials so participants can concentrate more, encouraged participants who are still passive in discussion activities by asking questions, and the teacher would act more as a facilitator, and provided space for participants to identify existing problems and make their respective conclusions before giving a final explanation of the activities carried out.

The learning activities were carried out in three stages of activity, namely introduction, core activity, and closing. The introduction and closing stage were still done the same as the First Cycle, but there were some changes being made for the core activity stage. Teacher began the core activity stage by doing a review first before going to an open discussion. During discussion activities, teacher encouraged all participants to share their opinions and would ask specific questions to passive participants. During experiment activities, teacher gave more opportunities for participants to evaluate and analyze what would be done and the results that would be obtained. Participants were also being encouraged to do the experiment activities independently, but still allowed a little help from parents or caretakers. Teacher invited all participants to observe and analyze their experiment, and shared their results through discussion activities. 
The results of the assessment and observation in Cycle 2 showed that, overall, there were an increase in the results of the assessment on the two aspects of development observed, namely critical thinking and problem solving skills. Some of the participants who tend to be passive in the First Cycle have started to show courage and confidence in conveying responses, opinions, or answering questions given by the teacher, even though it was only done occasionally or with guidance from parents or caretakers. Overall, participants have begun to show activeness in exploring and experimenting in learning activities, and have been able to follow the entire series of learning activities carried out. The results of the Second Cycle can be seen in Table 4 and Table 5.

Table 4. Comparison Results for Critical Thinking Skills in Second Cycle

\begin{tabular}{lcccc}
\hline \multicolumn{1}{c}{ Criteria } & \multicolumn{2}{c}{ First Cycle } & \multicolumn{2}{c}{ Second Cycle } \\
& Frequency & Percentage & Frequency & Percentage \\
\hline UD & 3 & $30 \%$ & 2 & $20 \%$ \\
SD & 1 & $10 \%$ & 0 & $0 \%$ \\
DE & 4 & $40 \%$ & 5 & $50 \%$ \\
ED & 2 & $20 \%$ & 3 & $30 \%$ \\
Total & 10 & 100 & 10 & 100 \\
\hline
\end{tabular}

Note : UD (Undeveloped), SD (Started to Develop), DE (Developed as Expected), ED (Extremely WellDeveloped)

Table 5. Comparison Results for Problem Solving Skills in Second Cycle

\begin{tabular}{ccccc}
\hline Criteria & \multicolumn{2}{c}{ First Cycle } & \multicolumn{2}{c}{ Second Cycle } \\
& Frequency & Percentage & Frequency & Percentage \\
\hline UD & 3 & $30 \%$ & 2 & $20 \%$ \\
SD & 2 & $20 \%$ & 1 & $10 \%$ \\
DE & 3 & $30 \%$ & 4 & $40 \%$ \\
ED & 2 & $20 \%$ & 3 & $30 \%$ \\
Total & 10 & $100 \%$ & 10 & $100 \%$ \\
\hline
\end{tabular}

Note : UD (Undeveloped), SD (Started to Develop), DE (Developed as Expected), ED (Extremely WellDeveloped)

Table 4 and 5 shows an increase in the level of learning achievement of participants after corrective actions were being implemented in learning activities. In the Second Cycle, $80 \%$ of participants has reached the criteria of "Developed As Expected" (DE) and "Extremely Well Developed" (ED) for critical thinking skills aspect, and for the problem solving skills aspects, $70 \%$ of participants has reached the criteria of "Developed As Expected" (DE) and "Extremely Well Developed" (ED). Based on these results, the corrective actions were considered successful in improving participants' critical thinking skills, but for problem solving skills aspects, corrective actions still needed to be taken.

Based on the observations made in Second Cycle, there were some reflective notes being taken to improve learning activities in the Third Cycle. Questions given specifically to encourage participants who have not been active in discussion activities were considered effective in encouraging participant's participation in learning activities. Participants become more active in providing responses and opinions about learning activities, so that longer time needed in discussion activities, and learning activities would last longer. Only a few participants still need more encouragement to be more involved in discussion activities. In Second Cycle, the teacher has already provided space for participants to identify existing problems and allow each participant to make their own conclusions before the teacher combined all the conclusions into a joint conclusion, but some participants still needed to be encouraged to share the results of their observations. 
DOI: $10.31004 /$ obsesi.v6i3.1722

\section{Third Cycle}

Third Cycle, which is the last cycle in this research, was carried out on March 9, 11, and 16, 2021 in three meetings, each of which was conducted for 45 minutes on Tuesday and Thursday. In Third Cycle, learning activities were still divided into three parts, namely introduction, core activities, and closing. The theme discussed in Third Cycle was about "Weather", but in this cycle the teacher focused more on discussing about different objects that could be used in certain weather. In this cycle, the children were being challenged to make objects related to a certain type of weather every meeting session to improve critical thinking and problem solving skills. Some corrective actions that was being implemented in Third Cycle were extended the duration of the learning activities to 45 minutes, provided opportunities for participants who tend to be passive to be able to give their opinions or responses first, before participants who are actively involved are given the opportunity to answer or provide responses or opinions, challenged each participant to try to experiment more to find solutions to existing problems, before explaining the solutions that can be done by each participant. The duration of the learning activities was extended because in Second Cycle, it was found that the teacher needed more time to involve each participant to be involved in discussion activities and answer questions given by the teacher.

In this cycle, the stages of learning activities were still carried out in three different stages of activity, namely introduction, core activity, and closing. With the time extension, the time divided into 5 minutes for the introduction and closing stage, and 35 minutes for the core activity. When the teacher did a review in the beginning of core activity, participants were being encouraged to shared what they remembered from the previous lessons. Teacher was also giving more freedom to participants to create their own version of objects that represent different types of weather using the materials given during experiment activities. When all participants were done, they presented their objects to the class. Conclusions were being made together as each participant would share their opinions and discussed together to make a joint conclusion.

At the end of Third Cycle, based on the results of observations made by the teacher as a researcher, it could be seen, overall, that there was an increase in Third Cycle. Most of the participants experienced an increase or were in the same level of developmental criteria as the Second Cycle. Participants who tended to be passive in First and Second Cycle were more active in participating in learning activities. Participants seemed more involved in solving existing problems and making conclusions from learning activities together. The results of observation of critical thinking and problem solving skills in Third Cycle can be seen in Table 6 and Table 7.

Table 6 and 7 shows that after corrective actions were being implemented in Third Cycle, there was an increase in the level of learning achievement of participants. In the Third Cycle, $90 \%$ of participants has reached the criteria of "Developed As Expected" (DE) and "Extremely Well Developed" (ED) for critical thinking and problem solving skills aspects. Based on these results, the corrective actions were considered successful in improving participants' critical thinking and problem solving skills.

Table 6. Comparison Results for Critical Thinking Skills in Third Cycle

\begin{tabular}{lcccc}
\hline Criteria & \multicolumn{2}{c}{ Second Cycle } & \multicolumn{2}{c}{ Third Cycle } \\
& Frequency & Percentage & Frequency & Percentage \\
\hline UD & 2 & $20 \%$ & 0 & $0 \%$ \\
SD & 0 & $0 \%$ & 1 & $10 \%$ \\
DE & 5 & $50 \%$ & 5 & $50 \%$ \\
ED & 3 & $30 \%$ & 4 & $40 \%$ \\
Total & 10 & 100 & 10 & 100 \\
\hline
\end{tabular}

Note : UD (Undeveloped), SD (Started to Develop), DE (Developed as Expected), ED (Extremely WellDeveloped) 
Table 7. Comparison Results for Problem Solving Skills in Third Cycle

\begin{tabular}{ccccc}
\hline \multirow{2}{*}{ Criteria } & \multicolumn{2}{c}{ Second Cycle } & \multicolumn{2}{c}{ Third Cycle } \\
\cline { 2 - 5 } & Frequency & Percentage & Frequency & Percentage \\
\hline UD & 2 & $20 \%$ & 0 & $0 \%$ \\
\hline SD & 1 & $10 \%$ & 1 & $10 \%$ \\
\hline DE & 4 & $40 \%$ & 5 & $50 \%$ \\
\hline ED & 3 & $30 \%$ & 4 & $40 \%$ \\
\hline Total & 10 & $100 \%$ & 10 & 100 \\
\hline
\end{tabular}

Note : UD (Undeveloped), SD (Started to Develop), DE (Developed as Expected), ED (Extremely WellDeveloped)

The reflecting stage of Third Cycle was done through observations. Researcher found that after corrective actions were being implemented, Participants were more actively involved in discussion activities and experiment activities. Learning time with a longer duration gave an opportunity for all participants to be more involved in learning activities. The activity of making different objects to represent certain types of weather made participants to be more involved in learning activities. Participants who tend to be passive in participating in learning activities were seen to be more involved in doing the given activities by demonstrating their ability to follow the instructions given by the teacher, and did not hesitate to ask questions when something needed to be asked. Some participants, seemed able to make creations with their own ideas even though they used the same learning materials. Participants were also seen to be more involved in making conclusions together, and appeared more confident in expressing their opinions or responses.

Based on the results of the Third Cycle, STEM Learning Method was able to enhance participants' critical thinking and problem solving skills. The improvement of both critical thinking and problem solving skills can be seen in the graphs in picture 1 and 2 .

In the three cycles that have been carried out, the 3-4 years old participants' critical thinking and problem solving skills had increased. Participants who are in the "Developed as Expected" and "Extremely Well Developed" criteria in critical thinking and problem solving skills increased from $30 \%$ to $90 \%$ at the end of Third Cycle. Based on the determined success indicators, that is, if more than $80 \%$ of the participants are in the "Developed as Expected" and "Extremely Well Developed" criteria, the corrective actions taken is declared successful. The graphs above shows that in Third Cycle, $90 \%$ of participants were already in the "Developed as Expected" and "Extremely Well Developed" criteria, which indicated that 9 out of 10 participants had developed good critical thinking and problem solving skills, so the research could be stopped at Third Cycle.

The results of this research are in accordance with the results of previous research which stated that STEM learning method can improve participants' ability to understand learning concepts, participant involvement in learning activities, and their critical thinking skills (Ardianti et al., 2020). STEM learning method gives an opportunity for children to conduct investigations or experiments, encouraging children to use their thinking skills to fulfill their curiosity with a scientific approach. In problem solving skills aspects, previous research stated that the application of the STEM learning method provides more opportunities for children to use their ideas to solve problems encountered in their daily life (Purwaningsih et al., 2020). The application of STEM learning method have an impact on improving children's problem solving skills. The use of experimental activities in this learning program encourages children to be directly involved in finding solutions to problems they encounter and implementing them in their daily life. 


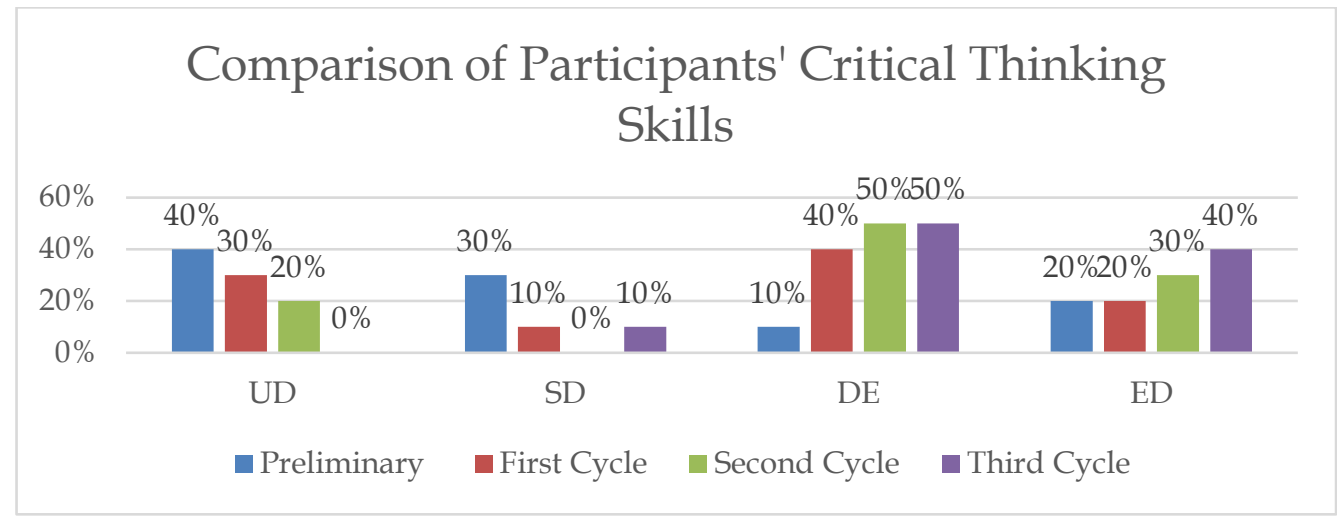

Picture 1. Comparison of Participants' Critical Thinking Skills

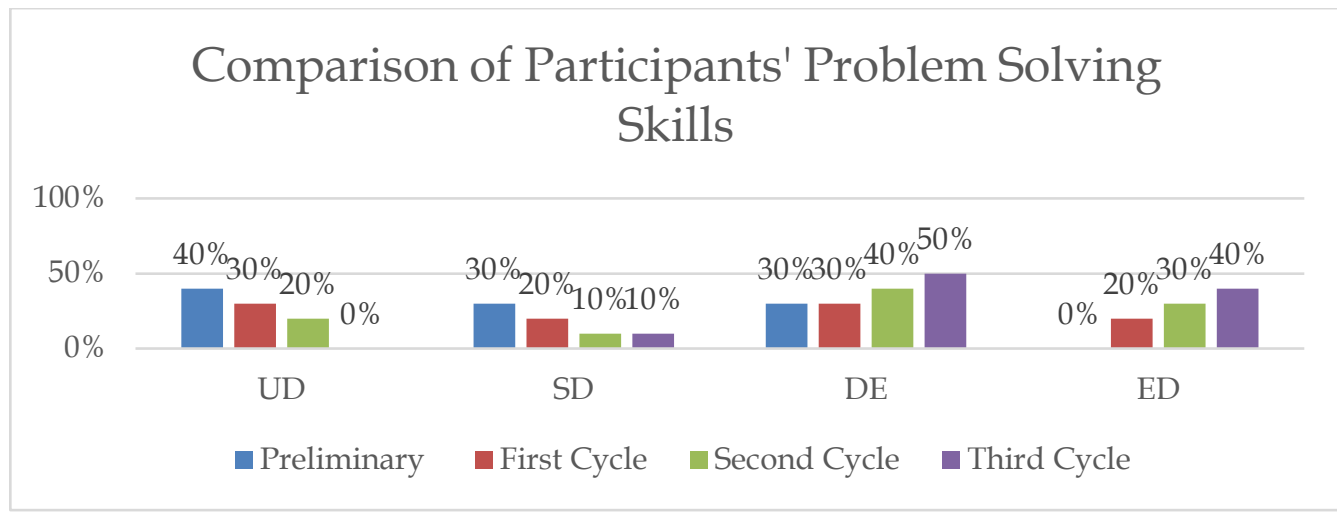

Picture 2. Comparison of Participants' Problem Solving Skills

\section{CONCLUSION}

The implementation of STEM learning method in virtual learning activities for children aged 3-4 years improves participants' critical thinking and problem solving skills. Learning participants have more confidence to express their ideas and opinions related to learning materials, and encourage participants to be directly involved in solving existing problems and applying them in everyday life. The use of appropriate learning method for early childhood affects children's development and their level of achievement in learning.

\section{ACKNOWLEDGEMENTS}

Acknowledgments are given to all learning participants involved in this research, as well as all parties who have supported and assisted the researcher so that the research can be carried out successfully.

\section{REFERENCES}

Agustin, M., Puspita, R. D., Nurinten, D., \& Nafiqoh, H. (2020). Tipikal Kendala Guru PAUD dalam Mengajar pada Masa Pandemi Covid 19 dan Implikasinya. Jurnal Obsesi : Jurnal Pendidikan Anak Usia Dini, 5(1), 334. https://doi.org/10.31004/obsesi.v5i1.598

Ardianti, S., Sulisworo, D., Pramudya, Y., \& Raharjo, W. (2020). The impact of the use of STEM education approach on the blended learning to improve student's critical thinking skills. Universal Journal of Educational Research, 8(3 B $)$, 24-32. https://doi.org/10.13189/ujer.2020.081503

Dyah, A. D. M., \& Setiawati, F. A. (2019). The Problem Solving Skills in Kindergarten Student Based on the Stages of Problem Solving. Jurnal Obsesi : Jurnal Pendidikan Anak Usia Dini, 3(1), 274. https://doi.org/10.31004/obsesi.v3i1.174

Fettig, A., Schultz, T. R., \& Ostrosky, M. M. (2016). Storybooks and Beyond: Teaching Problem Solving Skills in Early Childhood Classrooms. Young Exceptional Children, 19(3), 18-31. https://doi.org/10.1177/1096250615576803 
George S. Morrison. (2014). Early Childhood Education Today, Twelfth Edition (12th ed.). Pearson.

Gogoi, S. (2015). Importance's of teaching learning materials for young children. International Journal of Current Research, 7(09), 20269-20273.

Jha, A. K., \& Arora, A. (2020). The neuropsychological impact of E-learning on children. In Asian Journal of Psychiatry (Vol. 54). https:// doi.org/10.1016/j.ajp.2020.102306

Joseph, E. D., Kracht, C. L., Romain, J. S., Allen, A. T., Barbaree, C., Martin, C. K., \& Staiano, A. E. (2019). Young children's screen time and physical activity: Perspectives of parents and early care and education center providers. Global Pediatric Health, 6, 1-13. https://doi.org/10.1177/2333794X19865856

Kamarulzaman, W. binti. (2015). Affect of Play on Critical Thinking: What are the Perceptions of Preservice Teachers. International Journal of Social Science and Humanity, 5(12), 1024-1029. https:// doi.org/10.7763/IJSSH.2015.V5.598

Kingsley S., O., \& Ismail Z, M. (2015). Web Based E-learning System for Pre-school Kids. International Journal of Information Systems and Engineering, 3(1). https:// doi.org/10.24924/ijise/2015.11/v3.iss1/219.232

Lim, F. P. (2017). An Analysis of Synchronous and Asynchronous Communication Tools in eLearning. 230-234. https://doi.org/10.14257/astl.2017.143.46

Melo León, J. (2015). A Baseline Study of Strategies to Promote Critical Thinking in the Preschool Classroom. GiST Education and Learning Research Journal, 10(10), 113-127. https://doi.org/10.26817/16925777.270

Natalina M., D. (2018). Menumbuhkan Perilaku Berpikir Kritis Sejak Anak Usia Dini. Cakrawala Dini: Jurnal Pendidikan Anak Usia Dini, 6(1), 1-6. https:// doi.org/10.17509/cd.v6i1.10508

Peterson, A., Gaskill, M., \& Cordova, J. (2016). Connecting STEM Curriculum with Social Emotional Learning in Elementary Education. Undergraduate Research Journal, 22(1), 122.

Purwaningsih, E., Sari, S. P., Sari, A. M., \& Suryadi, A. (2020). The effect of stem-pjbl and discovery learning on improving students' problem-solving skills of the impulse and momentum topic. Jurnal Pendidikan IPA Indonesia, 9(4), 465-476. https://doi.org/10.15294/jpii.v9i4.26432

Risnanosanti, Susyla, D., \& Syofiana, M. (2019). Developing students critical thinking ability through lesson study. Journal of Physics: Conference Series, 1320(1). https://doi.org/10.1088/1742-6596/1320/1/012005

Siantajani, Y. (2020). Konsep Dan Praktik STE(A)M Di PAUD. PT Sarang Seratus Aksara.

Stella, C. (2017). Critical Thinking Skills: Effective Analysis, Argument and Reflection - Stella Cottrell - Google Books. Red Globe Press.

Struyf, A., De Loof, H., Boeve-de Pauw, J., \& Van Petegem, P. (2019). Students' engagement in different STEM learning environments: integrated STEM education as promising practice? International Journal of Science Education, 41(10), 1387-1407. https://doi.org/10.1080/09500693.2019.1607983

Suryana, D. (2016). Pendidikan Anak Usia Dini: Stimulasi \& Aspek Perkembangan Anak. Prenada Media.

Tientongdee, S. (2018). Development of Problem-Solving Skill by Using Active Learning for Student Teachers in Introductory Physics. Journal of Physics: Conference Series, 1144(1). https://doi.org/10.1088/1742-6596/1144/1/012002

Ulfah, S. M., \& Junaedah. (2018). Buku Saku Guru Pendidikan Anak Usia Dini. Penerbit Aksara Timur.

Widayati, A. (2014). Penelitian Tindakan Kelas. Jurnal Pendidikan Akuntansi Indonesia, 6(1), 1616. https://doi.org/10.21831/jpai.v6i1.1793

Wiyani. (2016). Konsep Dasar PAUD. PT Gava Media.

Wulandari, H., \& Purwanta, E. (2020). Pencapaian Perkembangan Anak Usia Dini di Taman Kanak-kanak selama Pembelajaran Daring di Masa Pandemi Covid-19. Jurnal Obsesi : Jurnal Pendidikan Anak Usia Dini, 5(1), 452. https://doi.org/10.31004/obsesi.v5i1.626 